\title{
PENINGKATAN KEMAMPUAN GERAK LOKOMOTOR MELALUI PERMAINAN BALAP KARUNG MENGAMBIL BOLA DI KELOMPOK B TK NEGERI PEMBINA KOTA TASIKMALAYA
}

\author{
Erna Lestari', Heri Yusuf Muslihin ${ }^{2}$, Edi Hendri Mulyana ${ }^{3}$ \\ ${ }^{1}$ Program Studi PGPAUD UPI Kampus Tasikmalaya \\ ${ }^{2}$ Program Studi PGPAUD UPI Kampus Tasikmalaya \\ ${ }^{3}$ Program Studi PGPAUD UPI Kampus Tasikmalaya
}

Email: heriyusuf@upi.edu

(Received: Mei 2019; Accepted: Mei 2019; Published: Juni 2019)

\begin{abstract}
This Classroom Action Research was motivated by the emergence of problems that were locomotor motility that had not been optimal in the children of B orange group in the Pembina State Kindergarten. So the researchers conducted a study on group B orange by using a sack racing game to take the ball. The general purpose of this study was to improve locomotor motility by using a game of sacking to pick up balls on a child of $B$ orange group in the State Elementary School. The specific purpose is to know the planning, the implementation of learning by using a sack racing game to take the ball in the children of group B orange in TK Negeri Pembina. This study uses collaborative classroom action research (CAR) methods. Research subjects were 17 children of $B$ group orange, consisting of eight girls and nine boys. This study was conducted in three cycles. Data collection techniques in this study use observation and documentation. The results showed an increase: 1) the ability of the teacher in planning learning by using sack racing game to take the ball in increasing the locomotor ability of children, 2) the ability of the teacher to carry out learning by using sack racing games to take the ball in increasing the locomotor motility of children, and 3 ) locomotor ability of children group B orange TK Negeri Pembina Tasikmalaya City.
\end{abstract}

Keywords: Sack Race, Locomotor Capabilit, Early Chilhood

\begin{abstract}
Abstrak
Penelitian Tindakan Kelas ini dilatarbelakangi adanya permasalahan yang muncul yaitu kemampuan gerak lokomotor yang belum optimal pada anak kelompok B orange di TK Negeri Pembina. Maka peneliti melakukan penelitian pada kelompok B orange dengan menggunakan permainan balap karung mengambil bola. Tujuan umum penelitian ini adalah untuk meningkatkan kemampuan gerak lokomotor dengan menggunakan permainan balap karung mengambil bola pada anak kelompok B orange di TK Negeri Pembina. Tujuan khususnya adalah untuk mengetahui perencanaan, pelaksanaan pembelajaran dengan menggunakan permainan balap karung mengambil bola pada anak kelompok B orange di TK Negeri Pembina. Penelitian ini menggunakan metode penelitian tindakan kelas (PTK) kolaboratif. Subjek penelitian adalah anak kelompok B orange yang berjumlah 17 anak, yang terdiri dari delapan orang anak perempuan dan sembilan orang anak laki-laki. Penelitian ini dilaksanakan dalam tiga siklus. Teknik pengumpulan data dalam penelitian ini menggunakan observasi dan dokumentasi. Hasil penelitian menunjukkan adanya peningkatan: 1) kemampuan guru dalam merencanakan pembelajaran dengan menggunakan permainan balap karung mengambil bola dalam meningkatkan kemampuan gerak lokomotor anak, 2) kemampuan guru dalam melaksanakan pembelajaran dengan menggunakan permainan balap karung mengambil bola dalam meningkatkan kemampuan gerak lokomotor anak, dan 3) kemampuan gerak lokomotor anak kelompok B orange TK Negeri Pembina Kota Tasikmalaya.
\end{abstract}

Kata Kunci : Balap Karung, Gerak Lokomotor, Anak Usia Dini 


\section{PENDAhuluan}

Menurut Ki Hajar Dewantara (Bapak Pendidikan Nasional Indonesia) pendidikan merupakan tuntutan di dalam hidup tumbuhnya anak-anak, adapun maksudnya yaitu menuntun segala kekuatan kodrat yang ada pada anakanak itu agar mereka sebagai manusia dan sebagai anggota masyarakat dapatlah mencapai keselamatan dan kebahagiaan setinggitingginya. Jadi dapat disimpulkan bahwa pendidikan merupakan bimbingan atau pertolongan yang diberikan oleh orang dewasa kepada perkembangan anak untuk mencapai kedewasaannya dengan tujuan agar anak cukup cakap melaksanakan tugas hidupnya sendiri tidak dengan bantuan orang lain.

Pendidikan anak usia dini secara umum merupakan suatu upaya pembinaan yang dilakukan melalui pemberian rangsangan pendidikan kepada anak sejak lahir sampai dengan usia enam tahun. Pendidikan anak usia dini bertujuan untuk membantu pertumbuhan dan perkembangan jasmani dan rohani agar anak memiliki kesiapan dalam memasuki pendidikan lebih lanjut. Permendikbud No 146 Tahun 2014 tentang Kurikulum PAUD Pasal 5 ayat 1 bahwa "struktur kurikulum PAUD memuat program-program pengembangan yang mencakup: a. nilai agama dan moral; b. fisik-motorik; c. kognitif; d. bahasa; e. sosialemosional; dan f. seni." Standar Pendidikan Anak Usia Dini Tingkat Pencapaian Perkembangan (TPP) khusus aspek perkembangan motorik kasar dalam Peraturan Menteri Pendidikan Nasional Nomor 58 Tahun 2009 yang seharusnya sudah dicapai anak usia 5-6 tahun meliputi: 1) melakukan gerakan tubuh secara terkoordinasi untuk melatih kelenturan, keseimbangan dan kelincahan, 2) melakukan koordinasi gerakan kaki-tangankepala dalam menirukan tarian atau senam, 3) melakukan permainan fisik dengan aturan, 4) terampil menggunakan tangan kanan dan kiri, 5) melakukan kegiatan kebersihan diri.

Pendidikan dapat mengembangkan ragam pengembangan potensi sejak usia dini, pengembangan metode tersebut dapat dilakukan dalam strategi dan metode dapat difasilitasi dengan pengembangan motorik.
Perkembangan motorik merupakan proses memperoleh keterampilan dan pola gerakan yang dapat dilakukan anak.

Bergerak bagi anak merupakan kebutuhan yang apabila tidak diperoleh akan membawa dampak perkembangan yang buruk. Anak suka dan butuh bergerak agar mampu tumbuh dan berkembang dengan baik. Gerak menjadi dasar bagi anak untuk mendapatkan kebutuhan dan mencapai kemajuan yang berarti dalam kehidupannya. Anak yang sedikit bergerak, penurut dan tahan duduk manis mungkin sangat menyenangkan bagi pendidik karena tidak terlalu merepotkan. Sebaliknya, anakanak yang banyak bergerak dan memiliki kebutuhan untuk bergerak tidak begitu disukai pendidik karena sulit dikendalikan.

Sebagaimana disinggung di awal bahwa bermain adalah satu kegiatan yang dapat mengembangkan kemampuan motorik anak. Bermain adalah suatu kegiatan yang dilakukan dengan atau tanpa mempergunakan alat yang menghasilkan pengertian atau memberikan informasi, memberi kesenangan maupun mengembangkan imajinasi pada anak. Antara 3 - 20\% waktu dan energy anak-anak dihabiskan untuk bermain (Pellegrini AD, Smith PK, 1998). Pergerakan yang terjadi dalam aktivitas bermain akan melibatkan organ tubuh baik dari sisi anatomisnya maupun sisi fisiologisnya. Pengalaman aktivitas gerak yang banyak meningkatkan kesehatan, kebugaran jasmani, dan komponen prilaku aktivitas fisik (Sholatuh H, Myrnawati CH, dan Moch Asmawi, 2017).

Menurut Suwandi (2012), "balap karung merupakan permainan yang termasuk jenis permainan anak tradisional karena memang telah dilakukan dalam waktu yang lama dan peralatan yang digunakan juga sederhana". Balap karung ini bisa dilakukan oleh anakanak, remaja, dewasa, hingga para orang tua, baik laki-laki maupun perempuan. Biasanya dikelompokkan berdasarkan tingkatan umur dan jenis kelaminnya. Kelompok anak-anak dimainkan oleh anak-anak demikian pula dengan kelompok lainnya. Balap karung ini selalu ramai ketika menjelang perayaan peringatan hari kemerdekaan RI atau sering 
disebut dengan peringatan "tujuh belasan". Hampir di setiap kampung, selalu menggelar berbagai perlombaan, salah satunya adalah lomba balap karung. Selain itu balap karung juga dapat melatih motorik kasar anak, melatih kelincahan, mengajarkan kemampuan sosial, berkompetensi dan membangun sportifitas.

Berdasarkan hasil observasi yang dilakukan di Kelompok B TK Negeri Pembina Kota Tasikmalaya mengenai proses pembelajaran menggunakan pemainan balap karung mengambil bola khusunya pada aspek kemampuan gerak lokomotor. Kenyataan yang ditemukan di lapangan yaitu berbagai keadaan di sekolah menunjukkan bahwa guru-guru di sekolah ini lebih banyak menstimulasi kemampuan kognitif dan motorik halus anak. Hampir setiap hari anak diajarkan tentang pengenalan huruf latin dan pembelajaran berhitung. Proses pembelajaran yang diberikan kepada anak pun lebih banyak menstimulasi kemampuan motorik halus seperti melalui kegiatan mewarnai, membuat kolase, meronce, menggunting, dan sebagainya. Kemampuan motorik kasar khususnya gerak lokomotor anak yang masih kurang terlihat saat peneliti melakukan asesmen awal terhadap anak. Ada beberapa aktivitas yang diberikan peneliti, di antaranya meloncat menggunakan karung, berjalan sebagai aba-aba sebelum memakai karung, berlari untuk mengambil karung yang ada di depan anak-anak dengan jarak yang agak jauh, serta mengekspresikan berbagai gerakan kepala, tangan atau kaki sesuai irama.

Belum berkembangnya kemampuan gerak lokomotor anak Kelompok B Orange TK Negeri Pembina Tasikmalaya, merupakan masalah yang harus dipecahkan. Untuk mendapatkan hasil pendidikan yang baik, perencanaan dan sarana memegang peranan penting dalam kegiatan belajar mengajar. Proses yang sistematis terdiri dari beberapa komponen seperti bahan kegiatan, metode, pengelompokkan anak didik dan media pembelajaran harus berjalan seimbang. Media pembelajaran yang digunakan harus bisa menarik perhatian anak agar fokus di dalam pembelajaran.
Dari keberhasilan tersebut penulis berupaya untuk membuat permainan yang diharapkan akan menarik minat anak dalam kegiatan peningkatan kemampuan gerak lokomotor yaitu dengan permainan balap karung mengambil bola. Alat yang digunakan adalah karung yang sudah diberi gambar dengan warna yang menarik perhatian anak. Karung yang digunakan dalam permainan ini adalah karung yang sesuai dengan ukuran anak.

\section{TINJAUAN PUSTAKA}

\section{Konsep Gerak Dasar Anak}

Gerak dasar lokomotor merupakan salah satu domain dari gerak dasar fundamental (fundamental basic movement), di samping gerak dasar non-lokomotor dan gerak dasar manipulatif. Gerak dasar lokomotor diartikan sebagai gerakan atau keterampilan yang menyebabkan tubuh berpindah tempat, sehingga dibuktikan dengan adanya perpindahan tubuh dari satu titik ke titik lain. Gerakan-gerakan tersebut merentang dari gerak yang sifatnya sangat alamiah mendasar seperti merangkak, berjalan, berlari, dan melompat hingga ke gerakan yang sudah berupa keterampilan khusus seperti meroda, guling depan, hingga handspring dan backhandspring.

Menurut Sugiyanto (1993, hlm.13), keterampilan gerak adalah kemampuan untuk melakukan gerakan secara efektif dan efisien. Keterampilan gerak merupakan perwujudan dari kualitas koordinasi dan contoh tubuh dalam melakukan gerakan. Keterampilan gerak diperoleh melalui proses belajar yaitu dengan cara memahami gerakan dan melakukan gerakan berulang-ulang dengan kesadaran pikir akan benar tidaknya gerak yang telah dilakukan. Menurut Suharjana (2010, hlm.8), gerak lokomotor adalah perpindahan tubuh dari satu tempat ke tempat yang lain. Perpindahan tersebut dapat dilakukan dengan cara yang berbeda-beda seperti jalan, lari, berguling, menggeser, merayap, dan sebagainya, serta arah yang berbeda-beda pula. 


\section{Jenis-jenis Gerak Lokomotor}

1. Gerak Dasar Berjalan

Berjalan adalah suatu proses menghilangkan keseimbangan dan mengembalikannya secara bergantian ketika bergerak ke depan dalam posisi tegak. Pada pelaksanaannya, gerak berjalan hanya menunjukkan sedikit sekali gerakan ke atas dan ke bawah serta gerakan ke samping. Lengan dan kaki bergerak secara berlawanan. Dalam berjalan, kaki bergerak secara bergantian, dengan salah satu kaki selalu kontak dengan bumi atau lantai. Ini berarti bahwa kaki yang melangkah harus ditempatkan pada bumi sebelum kaki yang lain diangkat.

\section{Gerak Dasar Berlari}

Dibandingkan dengan berjalan, berlari adalah pergerakan kaki yang cepat secara bergantian, pada saat yang sekejap, kedua kaki meninggalkan bumi sebelum salah satu kaki segera bertumpu kembali. Berlari dibedakan dari yang cepat (sprint) hingga yang pelan. Lutut dibengkokkan dan di angkat, kedua lengan berayun depan belakang dari bahu, dan siku bengkok.

Selama tahapan awal berlari (umur 2 tahun), seorang anak akan menghasilkan keseimbangan yang tidak stabil. Anak membuat gerakan kaki yang berlebihan, khususnya lutut dari kaki yang mengayun mengarah keluar kemudian berputar ke depan dalam persiapan untuk fase bertumpu. Aksi lutut ini dibarengi oleh kaki yang jarinya mengarah keluar. Gerakan yang berlebihan ini secara bertahap menghilang ketika tungkai anak menjadi lebih panjang dan lebih kuat.

\section{Gerak Dasar Melompat}

Melompat adalah suatu gerak lokomotor yang membuat tubuh terlontar ke udara yang menyebabkan tubuh lepas kontak dari tanah atau dari alat dan sesaat menimbulkan fase melayang. Baik sebagai aksi gerakan terpisah maupun ketika digabungkan dengan gerakan dasar yang lain, melompat terutama pada fase melayangnya merupakan aksi tubuh yang sangat menyenangkan bagi anak.

Lompatan biasanya dilakukan dengan dua arah; pertama, menaikkan tubuh secara vertikal (lurus ke atas) untuk mencapai ketinggian, atau, kedua, menaikkan tubuh dengan momentum horisontal untuk memperoleh jangkauan jarak yang jauh. Anak yang diajarkan melompat secara efektif, baik untuk ketinggian maupun untuk jarak jauh, pada dasarnya dipersiapkan untuk siap terlibat dalam berbagai aksi seperti permainan, dansa, senam, dan lain-lain, di mana anak perlu menguasai dengan baik kemampuan melompat.

\section{Gerak Dasar Meloncat}

Loncat adalah suatu gerakan mengangkat tubuh dari suatu titik ke titik yang lain yang lebih jauh atau lebih tinggi dengan ancangancang lari cepat atau lambat dengan menumpu dua kaki dan mendarat dengan kaki atau anggota lainnya dengan keseimbangan yang baik. (Mochamad Djumidar, 2004, hlm. 59).

Gerakan meloncat mula-mula tampak atau bisa berbentuk dari gerakan berjalan atau melangkah dari tempat yang agak tinggi ke tempat yang lebih rendah, misalnya menuruni tataran tangga rumah atau turun dari bangku pendek. Apabila anak berdiri di atas bangku pendek dan ingin turun dengan cara melangkah turun maka akan terjadi loncatan kecil karena kaki tumpu belum mampu menahan berat badan dengan menekuk lutut sampai kaki yang melangkah menapak di lantai. Gerakan seperti ini bisa membentuk gerakan meloncat.

\section{Pengertian Balap Karung}

Balap karung adalah salah satu lomba tradisional yang populer pada hari kemerdekaan Indonesia. Sejumlah peserta diwajibkan memasukkan bagian bawah badannya ke dalam karung kemudian berlomba sampai ke garis akhir. Meskipun sering mendapat kritikan karena dianggap memacu semangat persaingan yang tidak sehat dan sebagai kegiatan hura-hura, balap karung tetap banyak ditemui, seperti juga lomba panjat pinang, sandal bakiak, dan makan kerupuk. Lomba balap karung juga diapresiasi oleh pendatang dari luar negeri dengan langsung terlibat dalam perlombaan ini. Pada mulanya balap karung cukup terbatas kalangannya, diperayaan-perayaan dan di lingkungan 
tertentu, misalnya di sekolah, kampung ataupun lapangan umum. Tapi selanjutnya, di kantor-kantor pun dapat dilihat pula dengan peserta meliputi orang-orang dewasa, wanita maupun laki-laki, pegawai, mahasiswa dan sebagainya. Balap karung mengambil bola adalah permainan yang dilakukan sambil anak mengambil bola ketika menggunakan karung saat meloncat.

\section{Cara Memainkan Permainan Balap Karung Mengambil Bola}

Dalam penelitian ini cara yang dilakukan guru dalam kegiatan balap karung mengambil bola adalah:

1) Guru menyiapkan alat-alat yang digunakan untuk bermain, seperti tali atau pita yang digunakan untuk garis pembatas, karung bergambar untuk kegiatan bermain.

2) Guru menjelaskan kepada anak tentang apa saja alat dan bahan yang dipakai untuk bermain balap karung.

3) Guru membagi anak dalam kelompok kecil yang dalam satu kelompok terdapat tiga orang anak. Kemudian guru memberikan pengarahan untuk melakukan kegiatan bermain balap karung mengambil bola.

4) Guru merangsang kesiapan belajar anak dengan melakukan tanya jawab tentang kegiatan motorik kasar yang pernah anak lakukan berkaitan dengan gerak lokomotor sehingga anak mempunyai pengalaman tertentu.

5) Guru memulai permainan dengan memberikan aba-aba terlebih dahulu menggunakan tepuk tangan atau meniupkan peluit.

6) Anak melakukan kegiatan diawali dengan berlari terlebih dahulu untuk mengambil karung yang akan dipakainya. Setelah anak memakai karung lalu anak mulai dengan kegiatan berjalan memakai karung. Setelah berjalan anak melompat dan meloncat memulai permainan secara bergantian.

7) Selama kegiatan berlangsung peneliti dan guru kelas mengamati kegiatan anak. Apakah anak mampu melakukannya sendiri, melakukan dengan dibantu guru atau melakukan dengan bantuan temannya. Selain itu guru juga memberi motivasi kepada anak agar mau mengikuti kegiatan balap karung mengambil bola.

8) Guru mendampingi dan memberi semangat agar anak mampu melakukan setiap aspek yang ingin dicapai.

9) Guru memberikan reward kepada anak berupa bintang, acungan jempol dan sebagainya saat kegiatan berlangsung sehingga anak lebih termotivasi.

\section{METODE PENELITIAN}

Penelitian ini menggunakan metode penelitian kuantitatif kualitatif dengan jenis penelitian yang digunakan adalah Penelitian Tindakan Kelas (PTK) atau Classroom Action Research (CAR). Metode yang di gunakan dalam penelitian ini yaitu berupa Penelitian Tindakan Kelas kualitatif deskriptif, karena menghitung dan mendeskripsikan hasil pengamatan yang dilakukan dari kegiatan di lapangan. Desain penelitian yang di gunakan yaitu Penelitian Tindakan Kelas kolaboratif, yaitu dimana peneliti melibatkan pihak luar. Pihak luar disini yaitu dengan melibatkan guru kelas yang memegang kelas B orange. Jadi peneliti akan berkolaborasi dengan guru kelas B orange dengan tujuan agar hasil capaian pembelajaran yang diharapkan dapat dicapai dengan optimal. Lokasi penelitian yang digunakan dalam penelitian ini adalah Taman Kanak-kanak Negeri Pembina yang beralamat di Jalan Lingkar Dadaha belakang GGM Kelurahan Nagarawangi Kecamatan Cihideung Kota Tasikmalaya.

Variabel proses dalam penelitian ini adalah aktivitas guru dalam merencanakan pembelajaran dan aktivitas anak dalam mengikuti kegiatan permainan balap karung mengambil bola untuk meningkatkan kemampuan gerak lokomotor. Variabel hasil dalam penelitian ini adalah peningkatan kemampuan guru dalam merencanakan pembelajaran, peningkatan guru dalam melaksanakan pembelajaran, dan peningkatan kemampuan gerak lokomotor anak. Instrumen penelitian diartikan sebagai alat yang digunakan oleh peneliti untuk memperoleh data. Instrumen penelitian yang digunakan dalam penelitian ini adalah lembar observasi. 
Intsrumen pada penelitian ini mencakup lembar observasi guru dalam merencanakan pembelajaran, lembar observasi guru dalam melaksanakan pembelajaran dan lembar observasi kemampuan gerak lokomotor anak.

Dalam suatu kegiatan penelitian yang terpenting adalah pengumpulan data, hal ini bertujuan agar penelitian memperoleh data. Pengumpulan data dapat dilakukan dengan berbagai teknik pengumpulan data. Teknik pengumpulan data dalam penelitian ini yaitu teknik observasi dan teknik dokumentasi. Kerangka pengolahan dan analisis data akan di berlakukan pada setiap siklus tindakan sampai perbaikan pembelajaran di anggap maksimal. Untuk mengetahui presentase keberhasilan penelitian, maka data dianalisis menggunakan analisis deskriptif kualitatif. Menurut Ngalim Purwanto (Yuliani, 2017, hlm. 36) rumus yang digunakan yaitu sebagai berikut:

$$
\mathrm{NP}=\frac{\mathrm{R}}{\mathrm{SM}} \times 100 \%
$$

Keterangan:

$\mathrm{NP}=$ Nilai persen yang dicari/diharapkan

$\mathrm{R}=$ Skor mentah yang diperoleh siswa

$\mathrm{SM}=$ Skor maksimum ideal dari tes yang

bersangkutan

$100 \%=$ Bilangan tetap

Proses belajar mengajar dikatakan berhasil apabila anak mampu memberikan hasil yang baik atau dengan kata lain tercapainya tujuan yang diinginkan. Adapun pembatasan mengenai kriteria keberhasilan dapat ditentukan sebagai berikut:

1) Guru mengalami peningkatan kemampuan dalam merencanakan pembelajaran khususnya dalam permainan balap karung mengambil bola untuk meningkatkan kemampuan gerak lokomotor anak.

2) Guru mengalami peningkatan kemampuan dalam melaksanakan pembelajaran khususnya dalam permainan balap karung mengambil bola untuk meningkatkan kemampuan gerak lokomotor anak.

3) Anak mengalami peningkatan dalam kemampuan gerak lokomotor yang terdiri dari beberapa aspek di antaranya adalah berjalan, berlari, meloncat dan melompat.

\section{HASIL DAN PEMBAHASAN}

Sebelum melakukan tindakan, peneliti melakukan pengamatan untuk melihat kondisi awal kemampuan gerak lokomotor anak usia dini kelompok B. Pengamatan dilaksanakan pada hari selasa, 10 April 2018 dan menggunakan lembar observasi yang digunakan untuk mengetahui kemampuan awal anak dalam berlari, berjalan, melompat, dan meloncat. Pada saat observasi tema yang sedang dilaksanakan yaitu alat transportasi, sub tema kendaraan darat, sub-sub tema mobil. Peneliti mengobservasi kemampuan gerak lokomotor anak ketika sedang mengikuti kegiatan bermain. Pada saat guru sedang menjelaskan mengenai tema dan kegiatan yang akan dilaksankan pada hari itu masih banyak anak yang tidak memperhatikan guru ketika sedang menjelaskan, ada yang mengganggu temannya, ada yang ngobrol dengan temannya, ada yang memainkan mainan, ada juga yang lari-larian di dalam kelas, sehingga ketika guru bertanya kembali mengenai apa yang guru sampaikan, anak belum bisa menjawab dan masih menanyakan kembali apa yang guru sampaikan tersebut.

\begin{tabular}{|c|c|c|c|c|c|c|c|c|}
\hline \multirow{2}{*}{$\begin{array}{c}\text { Kriter } \\
\text { ia }\end{array}$} & \multicolumn{2}{|c|}{ Berlari } & \multicolumn{2}{|c|}{ Berjalan } & \multicolumn{2}{|c|}{ Melompat } & \multicolumn{2}{|c|}{ Meloncat } \\
\hline & $\begin{array}{c}\text { Jml } \\
\text { anak }\end{array}$ & $\begin{array}{l}\text { Prs } \\
\text { ntse }\end{array}$ & $\begin{array}{c}\text { Jml } \\
\text { anak }\end{array}$ & $\begin{array}{l}\text { Prs } \\
\text { ntse }\end{array}$ & $\begin{array}{c}\text { Jml } \\
\text { anak }\end{array}$ & $\begin{array}{l}\text { Prs } \\
\text { ntse }\end{array}$ & $\begin{array}{c}\text { Jml } \\
\text { ana } \\
\mathbf{k}\end{array}$ & $\begin{array}{l}\text { Prs } \\
\text { ntse }\end{array}$ \\
\hline BB & 10 & $\begin{array}{c}58,8 \\
2 \%\end{array}$ & 9 & $\begin{array}{l}52, \\
94 \\
\%\end{array}$ & 10 & $\begin{array}{l}58, \\
82 \\
\%\end{array}$ & 8 & $\begin{array}{c}47,9 \\
5 \%\end{array}$ \\
\hline MB & 5 & $\begin{array}{c}29,4 \\
1 \%\end{array}$ & 6 & $\begin{array}{l}35, \\
29 \\
\%\end{array}$ & 4 & $\begin{array}{l}23, \\
52 \\
\%\end{array}$ & 4 & $\begin{array}{c}23,5 \\
2 \%\end{array}$ \\
\hline BSH & 0 & 0 & 0 & 0 & 1 & $\begin{array}{l}5,8 \\
8 \%\end{array}$ & 3 & $\begin{array}{c}17,6 \\
4 \%\end{array}$ \\
\hline BSB & 0 & 0 & 0 & 0 & 0 & 0 & 0 & 0 \\
\hline JML & 17 & $\begin{array}{c}100 \\
\%\end{array}$ & 17 & $\begin{array}{c}100 \\
\%\end{array}$ & 17 & $\begin{array}{c}100 \\
\%\end{array}$ & 17 & $\begin{array}{c}100 \\
\%\end{array}$ \\
\hline
\end{tabular}

Berdasarkan hasil observasi pra

tindakan sesuai data diatas menunjukan bahwa kemampuan anak dalam berlari ada sepuluh anak atau 58,82\% termasuk ke dalam kriteria BB (Belum Berkembang), lima anak atau 29,41\% termasuk ke dalam kriteria MB (Mulai Berkembang), sedangkan pada indikator berjalan menunjukan sembilan anak atau $52,94 \%$ termasuk ke dalam kriteria BB, enam anak atau 35,29\% termasuk ke dalam kriteria MB, pada indikator melompat bahwa sepuluh anak atau $58,82 \%$ termasuk ke dalam kriteria $\mathrm{BB}$, empat anak atau $23,52 \%$ termasuk ke 
dalam kriteria $\mathrm{MB}$, satu anak atau 5,88\% termasuk ke dalam kriteria BSH, sedangkan pada indikator meloncat menunjukkan bahwa delapam anak atau $47,95 \%$ termasuk ke dalam kriteria BB, empat anak atau 23,52\% termasuk ke dalam kriteria $\mathrm{MB}$, tiga anak atau 17,64\% termasuk ke dalam kriteria $\mathrm{BSH}$.

\begin{tabular}{|c|c|c|c|c|c|c|c|c|c|}
\hline \multirow{3}{*}{ No } & \multirow{3}{*}{ Aspek } & \multicolumn{4}{|c|}{ Pra Tindakan } & \multicolumn{4}{|c|}{ Siklus I } \\
\hline & & \multicolumn{4}{|c|}{ Persentase (\%) } & \multicolumn{4}{|c|}{ Persentase } \\
\hline & & BB & MB & BSH & $\begin{array}{c}\text { BS } \\
\text { B }\end{array}$ & BB & MB & $\begin{array}{c}\text { BS } \\
\text { H }\end{array}$ & $\begin{array}{c}\text { BS } \\
\text { B }\end{array}$ \\
\hline 1 & Berlari & $\begin{array}{c}58,8 \\
2\end{array}$ & 29,41 & 0 & 0 & $\begin{array}{c}47,0 \\
5\end{array}$ & $\begin{array}{l}11, \\
76\end{array}$ & 0 & 0 \\
\hline 2 & Berjalan & $\begin{array}{c}52,9 \\
4\end{array}$ & 35,29 & 0 & 0 & $\begin{array}{c}35,2 \\
9\end{array}$ & $\begin{array}{l}17, \\
64\end{array}$ & $\begin{array}{c}5,8 \\
8\end{array}$ & 0 \\
\hline 3 & $\begin{array}{c}\text { Melompa } \\
\mathrm{t}\end{array}$ & $\begin{array}{c}58,8 \\
2 \\
\end{array}$ & 23,52 & 5,88 & 0 & $\begin{array}{c}41,1 \\
7\end{array}$ & $\begin{array}{l}17, \\
64\end{array}$ & 0 & 0 \\
\hline 4 & Meloncat & $\begin{array}{c}47,9 \\
5\end{array}$ & 23,52 & 17,64 & 0 & $\begin{array}{c}35,2 \\
9\end{array}$ & $\begin{array}{l}17, \\
64\end{array}$ & $\begin{array}{c}5,8 \\
8\end{array}$ & 0 \\
\hline
\end{tabular}

Pada indikator berlari saat pra tindakan yang termasuk kriteria BB (Belum Berkembang) ada sepuluh anak atau 58,82\%, pada kriteria MB (Mulai Berkembang) ada lima anak atau $29,41 \%$, Setelah menggunakan permainan balap karung mengambil bola dalam pembelajaran hasil tersebut berubah, di siklus I yang termasuk kriteria BB ada delapan anak atau 47,05\%, pada kriteria $\mathrm{MB}$ ada dua anak atau $11,76 \%$, pada kriteria BSH dan BSB tidak ada anak yang memenuhi kriteria tersebut.

Selain itu pada indikator berjalan pada pra tindakan terlihat ada sembilan anak atau $52,94 \%$ termasuk kriteria $\mathrm{BB}$, enam anak atau $35,29 \%$ termasuk kriteria MB, pada siklus I ada enam anak atau 35,29\% yang termasuk kriteria BB, tiga anak atau $17,64 \%$ yang termasuk kriteria $\mathrm{MB}$, dan satu anak atau 5,88\% termasuk kriteria BSH. Pada aspek melompat pada pra tindakan ada sepuluh anak atau $58,82 \%$ yang termasuk kriteria $\mathrm{BB}$, ada empat anak atau $23,52 \%$ yang termasuk kriteria MB dan satu anak atau 5,88\% yang mencapai kriteria BSH dan pada siklus I yang termasuk kriteria $\mathrm{BB}$ ada tujuh anak atau 41,17\%, pada kriteria MB ada tiga anak atau $17,64 \%$.

Pada indikator meloncat pada pra tindakan terlihat ada delapan anak atau 47,95\% yang termasuk kriteria $\mathrm{BB}$, ada empat anak atau $23,52 \%$ yang termasuk kriteria $\mathrm{MB}$, dan ada tiga anak atau $17,64 \%$ yang termasuk pada kriteria BSH, dan pada siklus I yang termasuk kriteria BB ada enam anak atau 35,29\%, tiga anak atau $17,64 \%$ yang termasuk kriteria MB, ada satu anak atau $5,88 \%$ yang termasuk kriteria BSH.

\begin{tabular}{|c|c|c|c|c|c|c|c|c|c|}
\hline \multirow{3}{*}{$\begin{array}{l}\mathbf{N} \\
\mathbf{0}\end{array}$} & \multirow{3}{*}{$\begin{array}{c}\text { Indikat } \\
\text { or }\end{array}$} & \multicolumn{4}{|c|}{ Siklus I } & \multicolumn{4}{|c|}{ Siklus II } \\
\hline & & \multicolumn{4}{|c|}{ Persentase (\%) } & \multicolumn{4}{|c|}{ Persentase (\%) } \\
\hline & & BB & MB & $\begin{array}{c}\text { BS } \\
\text { H }\end{array}$ & $\begin{array}{c}\text { BS } \\
\text { B }\end{array}$ & BB & $\begin{array}{l}\text { M } \\
\text { B }\end{array}$ & $\begin{array}{c}\text { BS } \\
\text { H }\end{array}$ & $\begin{array}{c}\text { BS } \\
\text { B }\end{array}$ \\
\hline 1 & Berlari & 47,0 & 11,7 & 0 & 0 & $\begin{array}{c}11, \\
8\end{array}$ & $\begin{array}{c}29 \\
4\end{array}$ & 23,5 & $\begin{array}{c}17, \\
6\end{array}$ \\
\hline 2 & Berjalan & 35,2 & 17,6 & 5,88 & 0 & $\begin{array}{c}17, \\
6\end{array}$ & $\begin{array}{c}11, \\
8\end{array}$ & 23,5 & $\begin{array}{c}29, \\
4\end{array}$ \\
\hline 3 & $\begin{array}{l}\text { Melomp } \\
\text { at }\end{array}$ & $\begin{array}{c}41,1 \\
7\end{array}$ & $\begin{array}{c}17,6 \\
4\end{array}$ & 0 & 0 & 35 & $\begin{array}{c}5,8 \\
8\end{array}$ & 23,5 & $\begin{array}{c}17, \\
6\end{array}$ \\
\hline 4 & $\begin{array}{l}\text { Melonca } \\
t\end{array}$ & 35,3 & 17,6 & 5,9 & 0 & 23 & $\begin{array}{c}29, \\
4\end{array}$ & 11,8 & $\begin{array}{c}17, \\
6\end{array}$ \\
\hline
\end{tabular}

Pada aspek berlari saat siklus I yang termasuk kriteria BB (Belum Berkembang) ada delapan anak atau 47,05\%, pada kriteria $\mathrm{MB}$ (Mulai Berkembang) ada dua anak atau $11,76 \%$, dan tidak ada satu pun yang mencapai kriteria BSH dan BSB. Pada siklus II yang termasuk kriteria BB ada dua anak atau $11,76 \%$, yang mencapai kriteria $\mathrm{MB}$ ada lima anak atau $29,41 \%$, yang mencapai kriteria BSH ada empat anak atau $23,52 \%$ dan ada tiga anak atau $17,64 \%$ yang termasuk kriteria BSB.

Selain itu pada indikator berjalan pada siklus I terlihat ada enam anak atau 35,29\% yang termasuk kriteria BB dan ada tiga anak atau $17,64 \%$ yang termasuk kriteria $\mathrm{MB}$, satu anak atau $5,88 \%$ yang termasuk kriteria $\mathrm{BSH}$ dan tidak ada anak yang mencapai kriteria BSB. pada siklus II yang termasuk kriteria BB ada tiga anak atau $17,64 \%$, pada kriteria MB ada dua anak atau $11,76 \%$, yang termasuk kriteria BSH ada empat anak atau 23,52\% dan ada lima anak atau $29,41 \%$ yang mencapai kriteria BSB.

Dalam aspek melompat pada siklus I terlihat ada tujuh anak atau $41,17 \%$ yang termasuk kriteria $\mathrm{BB}$, ada tiga anak atau $17,64 \%$ yang termasuk kriteria $\mathrm{MB}$, dan tidak ada anak yang mencapai kriteria BSH dan BSB. Pada siklus II yang termasuk kriteria BB ada enam anak atau 35,29\% yang termasuk kriteria MB ada satu anak atau 5,88\%, yang termasuk kriteria BSH ada empat anak atau 23,52\% dan yang termasuk kriteria BSB ada tiga anak atau $17,64 \%$.

Sedangkan pada aspek meloncat pada siklus I terlihat ada enam anak atau 35,29\% yang termasuk kriteria $\mathrm{MB}$ ada tiga anak atau 
$17,64 \%$ yang termasuk kriteria BSH ada satu anak atau 5,88\% dan tidak ada satu anak pun yang mencapai kriteria BSB. Pada siklus II yang termasuk kriteria BB ada empat anak atau 23,52\% yang termasuk kriteria MB ada lima anak atau $29,41 \%$ yang termasuk kriteria BSH ada dua anak atau $11,76 \%$ dan yang termasuk kriteria BSB ada tiga anak atau $17,64 \%$.

\begin{tabular}{|c|c|c|c|c|c|c|c|c|c|}
\hline \multirow{3}{*}{$\begin{array}{l}\mathbf{N} \\
\mathbf{0}\end{array}$} & \multirow{3}{*}{$\begin{array}{c}\text { Indikat } \\
\text { or }\end{array}$} & \multirow{2}{*}{\multicolumn{4}{|c|}{\begin{tabular}{|c|} 
Siklus II \\
Persentase (\%)
\end{tabular}}} & \multirow{2}{*}{\multicolumn{4}{|c|}{$\begin{array}{c}\text { Siklus III } \\
\text { Persentase (\%) }\end{array}$}} \\
\hline & & & & & & & & & \\
\hline & & BB & MB & $\begin{array}{c}\text { BS } \\
\mathrm{H}\end{array}$ & $\begin{array}{c}\text { BS } \\
\text { B }\end{array}$ & BB & MB & $\begin{array}{c}\text { BS } \\
\text { H }\end{array}$ & $\begin{array}{c}\text { BS } \\
\text { B }\end{array}$ \\
\hline 1 & Berlari & $\begin{array}{c}11,7 \\
6\end{array}$ & $\begin{array}{c}29,4 \\
1\end{array}$ & $\begin{array}{c}23,5 \\
2\end{array}$ & $\begin{array}{c}17,6 \\
4\end{array}$ & 0 & $\begin{array}{c}11,7 \\
6\end{array}$ & $\begin{array}{c}41,1 \\
7\end{array}$ & $\begin{array}{c}35,2 \\
9\end{array}$ \\
\hline 2 & $\begin{array}{l}\text { Berjala } \\
n\end{array}$ & $\begin{array}{c}17,6 \\
4\end{array}$ & $\begin{array}{c}11,7 \\
6\end{array}$ & $\begin{array}{c}23,5 \\
2\end{array}$ & $\begin{array}{c}29,4 \\
1\end{array}$ & $\begin{array}{c}11,7 \\
6\end{array}$ & $\begin{array}{c}17,6 \\
4\end{array}$ & $\begin{array}{c}23,5 \\
2\end{array}$ & $\begin{array}{c}35,2 \\
9\end{array}$ \\
\hline 3 & $\begin{array}{l}\text { Melom } \\
\text { pat }\end{array}$ & $\begin{array}{l}35,2 \\
9\end{array}$ & 5,88 & $\begin{array}{c}23,5 \\
2\end{array}$ & $\begin{array}{c}17,6 \\
4\end{array}$ & $\begin{array}{c}35,2 \\
9\end{array}$ & $\begin{array}{c}11,7 \\
6\end{array}$ & $\begin{array}{c}23,5 \\
2\end{array}$ & $\begin{array}{c}17,6 \\
4\end{array}$ \\
\hline 4 & $\begin{array}{l}\text { Melonc } \\
\text { at }\end{array}$ & $\begin{array}{c}23,5 \\
2\end{array}$ & $\begin{array}{c}29,4 \\
1\end{array}$ & $\begin{array}{c}11,7 \\
6\end{array}$ & $\begin{array}{c}17,6 \\
4\end{array}$ & $\begin{array}{c}17,6 \\
4\end{array}$ & $\begin{array}{c}11,7 \\
6\end{array}$ & $\begin{array}{c}11,7 \\
6\end{array}$ & $\begin{array}{c}47,0 \\
5\end{array}$ \\
\hline
\end{tabular}

Pada indikator berlari saat siklus II yang termasuk kriteria BB (Belum Berkembang) ada dua anak atau $11,76 \%$, ada lima anak atau $29,41 \%$ yang termasuk kriteria MB, ada empat anak atau 23,52\% yang termasuk kriteria BSH, dan ada tiga anak atau $17,64 \%$ yang termasuk kriteria BSB. Pada siklus III meningkat menjadi tidak ada satu anak pun yang memenuhi kriteria BB, ada dua anak atau $11,76 \%$ yang termasuk kriteria $\mathrm{MB}$, ada tujuh anak atau $41,17 \%$ yang termasuk kriteria $\mathrm{BSH}$, dan ada enam anak atau 35,29\% yang termasuk kriteria BSB.

Selain itu pada indikator berjalan pada siklus II terlihat ada tiga anak atau $17,64 \%$ yang termasuk kriteria BB, dua anak atau $11,76 \%$ yang termasuk kriteria $\mathrm{MB}$, ada empat anak atau 23,52\% yang termasuk kriteria $\mathrm{BSH}$, dan lima anak atau $29,41 \%$ yang termasuk kriteria BSB. Pada siklus III ada dua anak atau $11,76 \%$ yang termasuk kriteria $\mathrm{BB}$, ada tiga anak atau $17,64 \%$ yang termasuk kriteria MB, ada empat anak atau $23,52 \%$ yang termasuk kriteria BSH, dan ada enam anak atau 35,29\% yang termasuk kriteria BSB.

Pada indikator melompat pada siklus II ada enam anak atau 35,29\% yang termasuk kriteria BB, ada satu anak atau $5,88 \%$ yang termasuk kriteria $\mathrm{MB}$, ada empat anak atau 23,52\% yang termasuk ke dalam kriteria $\mathrm{BSH}$, dan ada tiga anak atau $17,64 \%$ yang termasuk kriteria BSB. Pada siklus III ada enam anak atau 35,29\% yang termasuk kriteria BB, ada dua anak atau $11,76 \%$ yang termasuk kriteria $\mathrm{MB}$, ada empat anak atau $23,52 \%$ yang termasuk kriteria $\mathrm{BSH}$, dan ada tiga anak atau $17,64 \%$ yang termasuk kriteria BSB.

Pada indikator meloncat pada siklus II ada empat anak atau $23,52 \%$ yang termasuk kriteria BB, lima anak atau $29,41 \%$ termasuk kriteria $\mathrm{MB}$, ada dua anak atau $11,76 \%$ yang termasuk kriteria BSH dan ada tiga anak atau $17,64 \%$ yang mencapai kriteria BSB dan pada siklus III ada tiga anak atau $17,64 \%$ yang termasuk kriteria $\mathrm{BB}$, ada dua anak atau $11,76 \%$ yang termasuk kriteria $\mathrm{MB}$ dan $\mathrm{BSH}$, dan delapan anak atau $47,05 \%$ yang termasuk kriteria BSB.

Hasil observasi perencanaan pembelajaran dari siklus I, siklus II dan siklus III mengalami peningkatan. Untuk lebih jelasnya dapat dilihat pada gambar berikut:

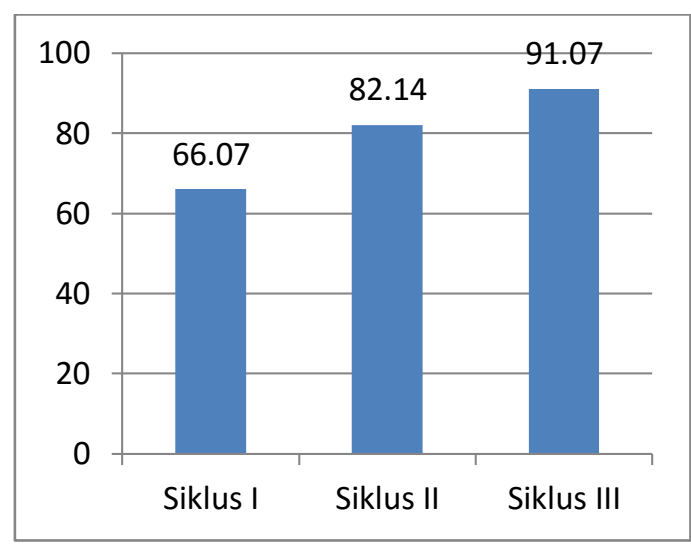

Gambar diatas menunjukkan adanya peningkatan dari siklus I, siklus II dan siklus III, hal tersebut karena adanya perbaikanperbaikan yang telah dilakukan pada setiap siklus. Maka dapat disimpulkan bahwa kemampuan guru dalam merencanakan pembelajaran meningkat dengan baik.

\section{KESIMPULAN}

Berdasarkan hasil Penelitian Tindakan Kelas yang telah dilaksanakan melalui tiga siklus yaitu siklus I, siklus II, dan siklus III mengenai permainan balap karung mengambil bola untuk meningkatkan kemampuan gerak lokomotor anak usia 5-6 tahun di TK Negeri 
Pembina Kota Tasikmalaya dapat diperoleh kesimpulan, yaitu sebagai berikut:

1) Perencanaan pembelajaran dengan menggunakan permainan balap karung mengambil bola untuk meningkatkan kemampuan gerak lokomotor anak usia 56 tahun di TK Negeri Pembina Kota Tasikmalaya yang telah disusun oleh peneliti sudah sesuai dengan kriteria keberhasilan. Peneliti membuat Rencana Pelaksanaan Pembelajaran Harian (RPPH) untuk digunakan sebagai pedoman dalam melaksanakan pembelajaran. Peneliti juga mempersiapkan lembar observasi kemampuan guru dalam melaksanakan pembelajaran maupun kemampuan guru dalam melaksanakan pembelajaran dengan menggunakan permainan balap karung dan peneliti juga mempersiapkan lembar observasi anak. Kemampuan guru dalam merencanakan pelaksanaan pembelajaran dengan menggunakan permainan balap karung mengambil bola untuk meningkatkan kemampuan gerak lokomotor anak usia dini pada setiap siklusnya mengalami peningkatan, hal ini dikarenakan adanya refleksi dan perbaikan-perbaikan yang telah dilakukan pada setiap siklusnya.

2) Pelaksanaan pembelajaran dengan menggunakan permainan balap karung mengambil bola untuk meningkatkan kemampuan gerak lokomotor anak usia 56 tahun di TK Negeri Pembina Kota Tasikmalaya ternyata dapat meningkatkan kemampuan guru dalam melaksanakan kegiatan pembelajaran menggunakan permainan balap karung mengambil bola. Hal ini dikarenakan adanya refleksi dan perbaikan-perbaikan yang telah dilaksanakan pada setiap siklusnya.

3) Kemampuan gerak lokomotor anak usia 5-6 tahun di TK Negeri Pembina Kota Tasikmalaya pada awalnya masih rendah dan perlu perbaikan dalam proses pembelajarannya. Setelah dilakukan penelitian untuk meningkatkan kemampuan gerak lokomotor anak melalui permainan balap karung mengambil bola yang dilaksanakan dalam tiga siklus, ternyata mengalami peningkatan yang cukup baik pada setiap siklusnya.

\section{SARAN}

Dalam rangka meningkatkan kualitas dalam pembelajaran untuk meningkatkan kemampuan gerak lokomotor anak usia 5-6 tahun, peneliti menyampaikan beberapa rekomendasi yaitu sebagai berikut:

1) Dalam upaya melaksanakan pembelajaran untuk meningkatkan kemampuan gerak lokomotor anak usia 5-6 tahun, guru hendaknya memilih metode yang dapat menarik perhatian serta minat anak yaitu melalui bermain balap karung mengambil bola. Permainan ini bisa dilakukan di luar ruangan maupun di dalam ruangan sesuai dengan kondisi dan keadaan pada saat akan melakukan permainan tersebut.

2) Bagi peneliti selanjutnya yang akan melakukan penelitian untuk meningkatkan kemampuan gerak lokomotor anak usia dini melalui permainan balap karung mngambil bola sapaya dapat berinovasi dengan melakukan berbagai variasi gerakan seperti gerakan secara lurus, menyamping atau zigzag dapat lebih menarik perhatian serta minat anak dalam proses pembelajaran. Sehingga kemampuan gerak lokomotor anak pun semakin meningkat.

\section{DAFTAR PUSTAKA}

Dewantara, Ki Hadjar. (1977). Karya: Pendidikan (Cetakan Kedua). Yogyakarta: Majelis Luhur Taman Siswa

Mochamad Djumidar A. (2004). Belajar Berlatih Gerak-gerak Dasar Atletik dalam Bermain. Jakarta: PT Raja Grafindo Persada

Permendiknas. No 58 Tahun 2009. Tentang standar Pendidikan Anak Usia Dini.

Permendikbud No 146 Tahun 2014 tentang Kurikulum PAUD 
Sholatuh H, Myrnawati CH, Moch Asmawi. (2017). Effect of Traditional Games, Learning Motivation and Learning Style on Childhoods Gross Motor Skill. InternTIONAL Journal of Education and Research. Vol 5 No 7 July 2017. P. 5366.

Smith, Peter, K., \& Pellegrini, A. (2013). Learning Through Play. Encyclopedia on early Chilhood Development. (pp. 15).

Sugiyanto. (1993). Pendidikan Atletik. Jakarta

Suharjana. (2004). Kebugaran Jasmani (Buku Pegangan Kuliah Mahasiswa FKI UNY). Yogyakarta: FIK UNY
Suwandi. (2012). Balap Karung (Permainan Tradisional -73). Di akses pada tanggal 29 januari 2014. Dari www. Tembi.org/2012/ensiklopedi/2012013 BALAP_KARUNG.html.

Yuliani. (2017). Pengembangan Media Papan Flanel Bergambar Untuk Meningkatkan Kemampuan Bercerita Anak-anak Usia Dini Kelompok B TK PGRI Cibeureum Kelurahan Kota Baru Kota Tasikmalaya. (Skripsi). UPI. 